\title{
Ortega y Gasset en la Argentina
}

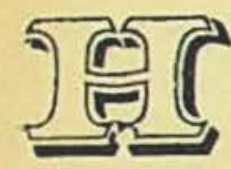

ACE doce años que Ortega y Gasset visitó la Argentina por primera vez y exaltó al país mozo con simpático entusiasmo. Adivinamos, en esa época, que lo había conquistado de diversas maneras e impreso en su espíritu huella durable. El año pasado volvió a Buenos Aires, en viaje triunfal, esperado y acogido como maestro. Sus conferencias interesaron a un público vastísimo. Sabemos que nadie expone con más elegancia, con más color, con más precisión que el filósofo español, sistemas y conflictos de ideas. Al regresar a España, sin celar su gratitud, el pensador en vela critica algunos aspectos de la vida argentina. Su lealtad lo obliga a dirigir admoniciones, a engarzar presagios.

En el número séptimo de El espectador, diario constante del ilustre escritor a quien interesan las más diversas cuestiones del mundo y del espíritu, se publica un ensayo consagrado a la vida argentina.

En los cenáculos ha provocado irritación la crítica franca y grave del maestro. Desde las columnas de La Nación él contesta a sus jóvenes adversarios y sonríe de sus diatribas. En lugar de renunciar a escribir sobre un tópico que engendra protestas, anuncia que va a insistir en sus observaciones y que cumple un deber difícil al denunciar falimientos.

$\mathrm{Si}$ intervenimos en este debate, si leemos con atención el estudio de Ortega y Gasset, nos parece injusta la vehemencia que pone una generación brillante y segura de sí en sus ataques. En efecto, el pensador viandante se ha limitado a indicar ciertas desviaciones en el espíritu argentino, ciertos errores peligrosos cuando se quiere conquistar la grandeza. Según él, el argentino de hoy no vive para sí, sino para los demás, no anhela la posesión de un reino interior, carece de intimídad, renuncia a una necesaria introspección. Le interesa sobre todo adquirir pronto fortuna, acumular proventos, avanzar en la jerarquía social. Estas tendencias van formando una existencia toda en sobrehaz, artificial y frenética, sin hondas perspectivas. En vez de individualidades completas topa el observador con hombres que han mutilado voluntariamente su ser y se consagran a una sola función, la de enriquecerse. El país, si no reacciona, puede convertirse en factoría, como en el melancólico augurio de Rodó en relación con los pueblos de América, ave- 
cinarse más bien a Tiro o a Cartago que a Atenas. Ingeniosamente refiere Ortega que el argentino muestra no sus ideas o sus gustos de artista sino su posición social, como quien hace admirar un monumento.

Lo que condena el filósofo en el Plata es muchas veces mal general de los pueblos hispano-americanos. El lo dice sin rudeza. El exceso de autoritarismo, por ejemplo, que va enflaqueciendo a los individuos, la dilatación de una voluntad ante la cual ceden las demás. Se confunde la apariencia exterior de la civilización y los instrumentos de elia con la verdadera cultura, y así en todas partes, antes de que surja el sabio o el creador, se fundan cátedras, se conceden granjerías, se crean puestos. De allí el divorcio continuo entre el ser y la apariencia, entre la realidad y la expresión que puede volvernos superficiales.

El escritor español-testigo lúcido-no se limita naturalmente a ajustar críticas. En su estudio hallamos los signos claros de una profunda simpatía por el país que ha visitado. Afirma que el argentino es un hombre admirablemente dotado, que todos se ufanan de vivir en un país en creciente, próspero, generoso y abundante, y que ese orgullo colectivo, que a veces puede confundirse con una suerte de bovarismo, ilusión difusa sobre el presente, es la verdadera fuerza de la nación, que incita y enhiesta a todos y está destinada a crear un gran pueblo moderno, lo que llama Ortega un pueblo histórico. ¿No satisface a los jóvenes argentinos esta declaración del profesor de $\mathrm{Ma}$ drid, lector y comentador de Hegel, sobre el futuro de su patria, destinada a servir la idea en el mundo, a culminar, a ejercer imperio? Ortega nota que a la formación de su ser moral ha contribuido la realidad argentina. Me parece que tal confesión de uno de los espíritus rectores de Europa debe halagar a un país nuevo. Todo es promesa en la vida platense, apunta el escritor, todo suscita esperanzas, todo lleva a la afirmación. Tierra de optimismo y de entono, de patriotismo y de dinamismo.

Fichte en el seno de una Alemania batida, pero con reales elementos de grandeza, predicaba un nacionalismo místico, que debía conducir a la libertad. En una Argentina acaso demasiado ufana, Ortega, filósofo inquieto, aspira a convertirse en reformador moral, ofrece normas, indica derroteros y prepara, para una nación que puede ser inficionada por males ciertos, un magnífico porvenir. Sin combatir el optimismo, lo depura, y seguro de que la promesa se convertirá pronto en realidad, evita, en todos los órdenes, la desmesura.-F R A N C I SC O GARCÎ́A CALDERÓN. Exclusivo para Atenea en Chile. 